\title{
DETERMINANTS OF HOUSEHOLD COOKING ENERGY CHOICE IN OYO STATE, NIGERIA
}

\author{
Olugbire 0.O. ${ }^{1}$, Aremu F.J. ${ }^{2}$, Opute O.H. ${ }^{1}$, Ojedokun C.A. ${ }^{1}$, Olawale 0.O. ${ }^{1}$, Adisa A. ${ }^{1}$ \\ ${ }^{1}$ Forest Economics and Extension Services Department, Forestry Research Institute of Nigeria, \\ lbadan, Nigeria \\ ${ }^{2}$ Department of Agricultural Economics, Obafemi Awolowo University, Ile-Ife, Nigeria \\ ${ }^{\star}$ E-mail: olugbireolutoyin@gmail.com
}

\begin{abstract}
Cooking energy is a vital aspect of life for the survival of any household. It is a daily affair since man must eat in order to continue to exist in this planet. Many types of cooking energy exist and households must appropriately choose among them. In making choices, certain factors influence households choice, hence the need for this study. The study examined the determinants of household cooking energy choice in Oyo state, Nigeria. Primary data was used for the study. The data was collected using structured questionnaires administered to 130 households. The households were sampled from main areas in Ibadan, Oyo state, Nigeria. Both descriptive and inferential statistics were employed to analyze the data. The result indicated that fuel wood, charcoal, kerosene, gas and electricity were the cooking energy used by households in the study area but kerosene was the most preferred. Kerosene is the cooking energy choice that households find it difficult to do without. The study further revealed that choice of cooking energy is influenced by some factors such as income of households, prevailing weather condition/ season of the year, types of houses/ dwelling place of households, price of cooking energy, nearness to sources and familiarity of household to a cooking energy choice. Households with high income per month often choose gas and electricity and used kerosene as a backup while those with low income per month often choose fuel wood, charcoal and kerosene. The level of satisfaction obtained from kerosene, gas and electricity were high, moderate and very high respectively. It is therefore recommended that government should provide means of increasing the welfare / standard of living of the households in the study area so that they will be able to afford gas and electricity as cooking energy choice. This will therefore protect them against the harmful effects of using charcoal, fuel wood and stove. Government and other stakeholders in power sector should also find permanent solution to the irregular electricity supply in the study area so that households will find its usage more dependable and reliable.
\end{abstract}

\section{KEY WORDS}

Energy, cooking, households, standard of living.

Household Energy consumption accounts for about $80 \%$ of total energy consumption in developing countries while cooking energy account for about $95 \%$ of this. Energy for cooking could be in form of fuel wood, charcoal, sawdust, kerosene, gas and electricity (Ogunsawa and Ajala, 2002). Cooking energy has environmental implication as well as affects income of women who primarily cook for family; since efficient cooking energy gives time for other income generating activities. Forests and other tree systems in Africa constitute an important component of household livelihood especially in generating cooking energy (Sene, 2000). According to World Bank studies in 2004, it was discovered that, there is a high relation between the level of poverty and the type of energy use for cooking by households. Fuel wood is the predominant fuel used in the rural areas of developing countries, whereas charcoal is the preferred fuel in urban centers replacing fuel wood as incomes rise (Arnold et al., 2006; Kituyi, 2002). Adeokun et al. (2003) reported that energy consumption pattern and level in Nigeria have produced a serious exploitative and disruptive environmental stress. The exploitative stress is most obvious 
in the amount of fuel-wood harvested daily to support the energy needs. The rate at which the natural vegetation has been exploited to meet the exponential human demand for energy has become highly disruptive of the ecological system. Jande (2005) reports that while energy is at the heart of economic and social development, its productions, transportation and use cause a wide range of major environmental problems at the local, national and global levels. Beside these short comings, modern energy is usually very expensive and beyond the reach of most rural and urban inhabitants. This has encouraged the use and preference for fuel-wood as a major source of fuel for domestic activities (Adedire, 2002). This study examines the factors influencing the choice of cooking energy used by households in the study area. It further seeks to examine the level of satisfaction households obtained from each choice of domestic energy used. It intends to fill gaps in information on energy use and also serve as a tool for investors in cooking energy.

\section{METHODOLOGY OF REDEARCH}

Study area and sampling techniques. The study was carried out in Ibadan, Oyo State, Nigeria. Ibadan is the capital of Oyo State and the third largest metropolitan area in Nigeria, with a population of 2, 338,659 (NPC, 2006). Ibadan is located in southwestern Nigeria but in the southeastern part of Oyo State. It is about $120 \mathrm{~km}$ east; bordered with the Republic of Benin in the forest zone and is also close to the boundary between the forest and the savanna. The total area is $1,190 \mathrm{sq} \mathrm{mi}\left(3,080 \mathrm{~km}^{2}\right)$. It has a large market for most household products and the demand keeps expanding as a result of rapid growth and increased urbanization. Primary data were obtained through questionnaires administered on households in the five different locations. A sample of 130 was selected with 26 respondents from each location. The questionnaires were analyzed using both descriptive and inferential statistics.

\section{RESULTS AND DISCUSSION}

Analysis of Socio-economic Characteristics of Cooking Households in the Study Area. The result analysis in table 1 revealed that the ages of members of household that engaged in active cooking activities range from 20 years to 50 years. 33.08\% were between 20 -30years, $29.03 \%$ were between $31-40$ years, $23.08 \%$ were between $41-50$ years while $14.61 \%$ were between $51 \%$ and above. This suggests that cooking household is young, active and energetic. They can be flexible in choosing among varieties of cooking energy available to them. The result in table 1 also showed that $43.08 \%$ of cooking household was single while $46.92 \%$ were married. $5.38 \%$ were widow/widower and $4.62 \%$ were divorced and divorcee. This implies that both singles and married actively cook in the study area. Similarly, table 1 also showed that majority of the cooking household was educated as $53.38 \%$ of them had tertiary education. $30.77 \%$ had secondary school education. $4.62 \%$ had primary education, $9.23 \%$ had no formal education. This finding suggest that the higher the educational status of household, the higher the tendency to take cooking as a responsibility. This further suggests that households with high educational status preferred cooking what they will eat rather than visiting restaurants for fast foods.

Moreover, table 1 showed that $16.92 \%$ were made up of two persons, $49.23 \%$ were between 3-4 persons. $24.62 \%$ were between 5-6 persons. $5.38 \%$ were between $7-8$ persons while $3.85 \%$ had more than 9 persons. This showed that the households in the study area have moderate family size which is a reflection of high educational status. Table one also showed that $26.92 \%$ of the household is surviving on wage only. $23.85 \%$ were both wage earner as well as self-employed. $22.31 \%$ survived only on their own personal business while $26.92 \%$ were unemployed thus; they depend on other people for survival. 
Table1 - Socio-economic characteristics of respondents

\begin{tabular}{|c|c|c|}
\hline Characteristics & Frequency & Percentage \\
\hline 1 & 2 & 3 \\
\hline \multicolumn{3}{|c|}{ Age in years } \\
\hline $20-30$ & 43.0 & 33.08 \\
\hline $31-40$ & 38.0 & 29.23 \\
\hline $41-50$ & 30.0 & 23.08 \\
\hline $51-60$ & 12.0 & 9.23 \\
\hline \multicolumn{3}{|l|}{$>60$} \\
\hline Total & 130.0 & 100.0 \\
\hline \multicolumn{3}{|c|}{ Marital Status } \\
\hline Single & 56.0 & 43.08 \\
\hline Married & 61.0 & 46.92 \\
\hline Widow/widower & 7.0 & 5.38 \\
\hline Divorced & 6.0 & 4.62 \\
\hline Total & 130 & 100 \\
\hline \multicolumn{3}{|c|}{ Educational Status } \\
\hline No formal Education & 12.0 & 9.23 \\
\hline Primary Education & 6.0 & 4.62 \\
\hline Secondary Education & 40.0 & 30.77 \\
\hline Tertiary Education & 72.0 & 55.38 \\
\hline Total & 130.0 & 100.0 \\
\hline \multicolumn{3}{|c|}{ Family size } \\
\hline 2 persons & 22.0 & 16.92 \\
\hline 3-4 persons & 64.0 & 49.23 \\
\hline 5-6 persons & 32.0 & 24.62 \\
\hline 7-8 persons & 7.0 & 5.38 \\
\hline More than 9 persons & 5.0 & 3.85 \\
\hline Total & 130.0 & 100.0 \\
\hline \multicolumn{3}{|c|}{ Types of occupation } \\
\hline Wage only & 35.0 & 26.92 \\
\hline Wage and self employed & 31.0 & 23.85 \\
\hline Self employed only & 29.0 & 22.31 \\
\hline Unemployed & 35.0 & 26.92 \\
\hline Total & 130.0 & 100.0 \\
\hline \multicolumn{3}{|c|}{ Type of dwelling place } \\
\hline Single room & 23.0 & 17.69 \\
\hline A room and parlour & 25.0 & 19.23 \\
\hline 2\&3 Bedroom & 50.0 & 38.46 \\
\hline Duplex & 26.0 & 20.00 \\
\hline Detached house & 6.0 & 4.62 \\
\hline Total & 130.0 & 100.0 \\
\hline \multicolumn{3}{|c|}{ Income range (\#) (per month) } \\
\hline 18,000 and below & 24.0 & 18.46 \\
\hline $18001-40000$ & 38.0 & 29.23 \\
\hline $40001-80000$ & 33.0 & 25.38 \\
\hline $80001-100000$ & 22.0 & 16.92 \\
\hline$>100,000$ & 13.0 & 10.00 \\
\hline Total & 130.0 & 100.0 \\
\hline \multicolumn{3}{|c|}{ Types of cooking energy use } \\
\hline Fuel wood & 8.0 & 6.15 \\
\hline Charcoal & 12.0 & 9.23 \\
\hline Kerosene & 65.0 & 50.0 \\
\hline Gas & 30.0 & 23.08 \\
\hline Electricity & 15.0 & 11.54 \\
\hline Total & 130.0 & 100.00 \\
\hline \multicolumn{3}{|c|}{ Do you use more than one cooking energy } \\
\hline Yes & 128.0 & 98.46 \\
\hline No & 2.0 & 1.54 \\
\hline Total & 130.0 & 100.00 \\
\hline
\end{tabular}


RJOAS, 4(52), April 2016

\begin{tabular}{|c|c|c|}
\hline 1 & 2 & 3 \\
\hline & Most preferred cooking energy & 30.00 \\
\hline Fuel wood & 39.0 & 20.77 \\
\hline Charcoal & 27.0 & 23.85 \\
\hline Kerosene & 31.0 & 10.00 \\
\hline Gas & 13.0 & 15.38 \\
\hline Electricity & 20.0 & 100.0 \\
\hline Total & 130.0 & 46.15 \\
\hline \multicolumn{2}{|c|}{ Reason for preference } \\
\hline It is cheap & 60.0 & 12.31 \\
\hline Easily accessible & 16.0 & 31.54 \\
\hline More reliable & 41.0 & 6.92 \\
\hline Effectiveness & 9.0 & 3.08 \\
\hline Familiarity & 4.0 & 100.00 \\
\hline Total & 130.0 & \\
\hline
\end{tabular}

Source: Field survey, 2014.

The results in table 1 also showed that $17.69 \%$ dwelled in a single room. $19.23 \%$ dwelled in a room and parlor apartment, 38.46\% dwelled in 2 and 3 Bedroom. $20.00 \%$ dwelled in a duplex while $4.62 \%$ dwelled in detached houses. The result in table 1 further showed that $18.46 \%$ of the households earn a maximum of $\# 18,000$ per month. $29.23 \%$ earned between 18,001- 40,000 monthly, 25.38\% earns \$40,001- \$80,000, 16.92\% earns \$80,001- \$100,000 and $10 \%$ earns more than 100,000 per month. This implies that both low and high income earners make cooking energy choice though it may differ.

Table 1 similarly showed that $6.15 \%$ of the household choose fuel wood as cooking energy, $9.23 \%$ choose charcoal, $50.0 \%$ choose kerosene, and $23.08 \%$ used gas while $11.54 \%$ used electricity. This shows that kerosene is the central cooking energy choice in the study area. $98 \%$ of them agreed that they us more than one types of cooking energy but $1.54 \%$ adhered to only one type. Similarly, table 1 revealed that $30 \%$ of the household preferred fuel wood as cooking energy to other types of cooking energy. $20.77 \%$ preferred charcoal, $23.85 \%$ preferred kerosene, and $10 \%$ preferred gas while $15.38 \%$ preferred electricity to others. These results agree with findings of Solar Cooking Archive (2011) who stated that socio-economic characteristics of households influence households' choice of cooking energy per time. It further states that a change in any of the characteristics has the tendency of changing the household choice.

Analysis of Choice of cooking energy used based on households dwelling place. Table 2 revealed that the nature of households' dwelling place determines the choice of cooking energy made by households in the study area. It therefore showed that kerosene $(7.69 \%)$ was mainly used by household living in a single room. This was followed by fuel wood $(3.85 \%)$, charcoal $(3.08 \%)$ and electricity $(2.31 \%)$ while none $(0.00 \%)$ used gas as their cooking energy. This agrees with Stephen (2011) who suggested that household living in a single room may not be able to afford the cost of using gas energy; and since only a single room was available, there may be the problem of space such as where to put the gas cylinder and other associated gadgets. Table 2 also showed that households in room and parlor apartment similarly used kerosene $(10.77 \%)$ as the chief cooking energy but this was followed charcoal $(3.08 \%)$ while fuel wood and electricity (2.31\%) were used at the same rate. It revealed that only $0.77 \%$ used gas for cooking. This suggests that the spacious the dwelling place of households, the higher the ability to make choice among the cooking energy.

Table 2 also showed that households in $2 \& 3$ bed rooms flat mainly used kerosene $(19.23 \%)$ as the main cooking energy. This was followed by gas (7.69\%). These type of households used charcoal and electricity at the same rate $(4.62 \%)$ but only $2.31 \%$ of the used fuel wood. This is may be because gas, electricity and kerosene are more efficient and less harmful in terms of neatness and smoke evolvement. The result in table 2 also revealed that 
households in duplexes used gas (9.23\%) as his main cooking energy. This is then followed by kerosene $(6.15 \%)$ and electricity $(3.08 \%)$ respectively. Only few $(1.54 \%)$ of the households still used charcoal while none used fuel. This thus suggested that household dwelling place determines the cooking energy choice. A specific cooking energy choice is more suitable for households living in an apartment. Moreover, table 2 also showed that kerosene was the chief cooking energy used by dwellers of detached houses in the study area. This was followed by gas $(1.54 \%)$ and electricity $(0.77 \%)$. None of them used fuel wood and charcoal $(0.00 \%)$. In summary, table 2 revealed that kerosene $(46.92 \%)$ was also the major choice of cooking energy of all households in the study area. Gas (19.23\%), electricity (13.08\%) and charcoal (12.30\%) then followed. Fuel wood $(8.47 \%)$ was found to be the last cooking energy choice that any households will used in the study area.

Table 2 - Choice of cooking energy according to types of dwelling place of Households

\begin{tabular}{|l|c|c|c|c|c|c|}
\hline & \multicolumn{5}{|c|}{ Types of cooking energy } \\
\hline Types of dwelling places & Fuel wood & Charcoal & Kerosene & Gas & Electricity & Total \\
\hline Single room & $5(3.85)$ & $4(3.08)$ & $10(7.69)$ & $0(0.00)$ & $3(2.31)$ & $23(17.69)$ \\
\hline one room \& parlor & $3(2.31)$ & $4(3.08)$ & $14(10.77)$ & $1(0.769)$ & $3(2.31)$ & $25(19.23)$ \\
\hline 2 \& 3 bedroom flat & $3(2.31)$ & $6(4.62)$ & $25(19.23)$ & $10(7.69)$ & $6(4.62)$ & $50(38.46)$ \\
\hline Duplex & $0(0)$ & $2(1.54)$ & $8(6.15)$ & $12(9.23)$ & $4(3.08)$ & $26(20.00)$ \\
\hline Detached house & $0(0.00)$ & $0(0.00)$ & $4(3.08)$ & $2(1.54)$ & $1(0.77)$ & $6(4.62)$ \\
\hline \multicolumn{1}{|c|}{ Total } & $11(8.47)$ & $16(12.30)$ & $61(46.92)$ & $25(19.23)$ & $17(13.08)$ & $130(100)$ \\
\hline
\end{tabular}

Source: Field survey, 2014.

Analysis of Choice of cooking energy based on monthly income of households. Table 3 showed that none of the households that earned maximum of $\$ 18,000.00$ per month chose gas as cooking energy. The households that chose fuel wood and charcoal were the same in terms of percentage (3.85\%). Kerosene $(7.69 \%)$ was the major choice of cooking energy while $3.08 \%$ depends on electricity for cooking. This is because they cannot afford the enormous price of using gas but charcoal and kerosene. Similarly, fuel wood can easily be sourced from their immediate environment with little or no cost.

Table 3 also showed that households that earned between $18,001-\$ 40,000$ per month used charcoal, gas and electricity at the same rate (3.85\%). Kerosene (15.38\%) was the main cooking energy but fuel wood (2.31\%) was the last choice. Table 3 also showed that kerosene was still the major cooking energy for households that earned between $\$ 40,001-\$ 80,000$ per month. But used $7.69 \%$ used gas while $2.31 \%$ charcoal and electricity were used at the same rate. Fuel wood was also the least choice. This is because increase in income enables them to be able to afford gas and electric cooking gadgets such gas cookers, electric pots and so on. This confirms Stephen (2011) who stated that, the higher the income of households, the higher their tendency to choose gas and electricity which are more comfortable and efficient to use than fuel wood and charcoal that have lots of side effects and stressful to use.

Table 3 further revealed that none of the households with monthly income of between $\# 80,001-\$ 100,000$ chose fuel wood as cooking energy. Majority of them depends on electricity $(6.15 \%)$ and gas $(5.38 \%)$ while only $1.54 \%$ still used charcoal. Table 3 similarly showed that gas and electricity $(5.85 \%)$ were the chief choice of cooking energy of households that earned more than 100,000 per month in the study area. This showed that as households' income increases, choice of cooking energy changes. It tends move from fuel wood with minimum cost and maintenance to gas and electricity with higher cost and maintenance; but with high comfort and safety. High income earners used kerosene as the last choice of cooking energy when there is power failure or the cylinder got exhausted unaware. The reverse was the case for low income earners who chose kerosene as the main cooking energy. Most of the low income earners do not always considered gas while only few occasionally used electricity when power supply is 
available. The result in table 3 supports Zaku et al., (2013) who stated that poverty rate strongly suggests the use of wood fuel as cooking fuel. As household income increases, a transition occur which is often referred to as the "fuel ladder". Fuel ladder is described as the situation where fuel wood and charcoal, which occupy the lower rungs of the ladder, are then substituted by kerosene, gas and commercial electricity as you rise up through the rungs (Brouwer and Falcao, 2004).

Table 3 - Choice of cooking energy according to monthly income of household

\begin{tabular}{|c|c|c|c|c|c|c|}
\hline \multirow{2}{*}{$\mathrm{n} / \mathrm{n}$} & \multicolumn{5}{|c|}{ Type of cooking energy } \\
\cline { 2 - 7 } & Fuel wood & Charcoal & Kerosene & Gas & Electricity & Total \\
\hline \#18,000\& above & $5(3.85)$ & $5(3.85)$ & $10(7.69)$ & $0(0.00)$ & $4(3.08)$ & $24(18.46)$ \\
\hline \#18,001-\$40,000 & $3(2.31)$ & $5(3.85)$ & $20(15.38)$ & $5(3.85)$ & $5(3.85)$ & $38(29.23)$ \\
\hline \#0,001-\#80,000 & $2(1.54)$ & $3(2.31)$ & $15(11.54)$ & $10(7.69)$ & $3(2.31)$ & $33(25.38)$ \\
\hline \#80,001-\#100,000 & $0(0.00)$ & $2(1.54)$ & $5(3.85)$ & $7(5.38)$ & $8(6.15)$ & $22(16.92)$ \\
\hline$>100,000$ & $0(0.00)$ & $0(0.00)$ & $3(2.31)$ & $5(3.85)$ & $5(5.85)$ & $13(10.00)$ \\
\hline Total & $10(7.69)$ & $15(11.54)$ & $53(40.77)$ & $27(20.77)$ & $25(19.23)$ & $130(100.0)$ \\
\hline
\end{tabular}

Source: Survey, 2014.

Analysis of household choice of cooking energy based on occupation. Table 4 showed that $11.54 \%$ of households with occupation that gives only wages used kerosene, $6.15 \%$ used fuel wood and $5.38 \%$ used charcoal as their major cooking energy. Similarly, $14.62 \%$ of households that earns only salary used kerosene, $3.84 \%$ used charcoal, and $2.31 \%$ used fuel wood; $1.54 \%$ used gas and electricity respectively. Table 4 also showed that $7.69 \%$ of households that earned both wage and salary used gas, $5.38 \%$ used kerosene and $4.62 \%$ used electricity as their major cooking energy. Only $4.61 \%$ used both fuel wood and charcoal altogether. The result in table 4 also revealed that most of the unemployed households chose fuel wood (11.54\%) and kerosene $(8.46 \%)$ as their major cooking energy. $4.62 \%$ chose charcoal and $2.31 \%$ choose electricity. None of them choose gas because they cannot afford it. This suggested that occupation of household influences their choice of cooking energy. An occupation with high income will enable the households to choose cooking energy types that offers more comfort, more efficiency and safety while occupation with less income restrict the households in their choice. This agrees with Ogbonna (1999) who reported that occupation influences the level of income of household which in turns have effect on their choice of cooking energy. High paying occupation make it possible for households to afford sophisticated cooking energy equipment such as gas cooker, electric kettle, pots, judge, micro wave and so on while low paying occupation set limits to households choice of cooking energy.

Table 4 - Choice of cooking energy and types of occupation

\begin{tabular}{|c|c|c|c|c|c|c|}
\hline \multirow{2}{*}{$n / n$} & \multicolumn{6}{|c|}{ Type of cooking energy } \\
\hline & Fuel wood & Charcoal & Kerosene & Gas & Electricity & Total \\
\hline \multicolumn{7}{|c|}{ Types of occupation } \\
\hline Wage earning only & $8(6.15)$ & $7(5.38)$ & $15(11.54)$ & $3(2.31)$ & $2(1.54)$ & $35(26.92)$ \\
\hline Salary earning only & $3(2.31)$ & $5(3.84)$ & $19(14.62)$ & $2(1.54)$ & $2(1.54)$ & $31(23.85)$ \\
\hline Wage and salary earning & $3(2.31)$ & $3(22.31)$ & $7(5.38)$ & $10(7.69)$ & $6(4.62)$ & $29(22.31)$ \\
\hline Unemployed & $15(11.54)$ & $6(4.62)$ & $11(8.46)$ & $0(0.00)$ & $3(2.31)$ & $35(26.92)$ \\
\hline Total & $29(22.31)$ & $21(16.15)$ & $52(40.00)$ & $15(11.54)$ & $13(10.00)$ & $130(100.0)$ \\
\hline
\end{tabular}

Source: Field survey, 2014.

Factors influencing households' choice of cooking energy used in the study area. Table 5 showed that income $(33 \%)$ of households was a major factor that influenced choice of cooking energy in the study area. 33\% of the household reported that they chose the type of cooking energy they used based on what their income could afford either it satisfies them or not. 
Table 5 also revealed that type of dwelling place was another factor that influenced households' choice of cooking energy. $26 \%$ of the households said that where they dwell greatly determined the choice of cooking energy that they used because of safety and convenience. $6.15 \%$ opted for gas because other types of cooking energy will not be convenient in the types of accommodation they dwell in. $5.38 \%$ said they opted for charcoal based on the type of house they well in. Some said they have enough space and do put the charcoal pots outside which reduce the effect of smokes and heat. $3.08 \%$ chose electricity because there was regular supply of electricity in their house. Moreover, the nature of materials used to build and decorate the house doesn't condone the use of certain types of cooking energy especially those that evolves smokes. $1.54 \%$ depends on kerosene because they live in houses where all tenants cooked in a common kitchen, some cooks in their room while some cooks in front of their room.

Table 5 also revealed that weather-of-the-day/ season of the year influences their choice of cooking energy. $8.46 \%$ reported that charcoal was the best choice for them in hot weather and dry season. This was because during dry season, charcoal is always cheap, dry and efficient. 3.85\% said electricity was their choice especially in dry weather though it can be used in any weather condition and season but its irregularity in terms of supply especially made it undependable and inefficient. $2.31 \%$ said fuel wood was their choice of cooking energy in hot weather and dry season but kerosene in raining weather/ season $1.54 \%$ said weather do not have much effect on kerosene and gas as households choice of cooking energy because there supply and usage were not influenced by weather. Table 5 also revealed that familiarity of household to a particular choice of cooking energy influence their choice. $14.63 \%$ said they chose the cooking energy because they are used to them since childhood and that was what they grew up with.

The result in table 5 also revealed that the nearer a cooking energy source is to households, the higher the tendency that households will make use of such energy for cooking. This is evidenced in the work of Zaku et. al., (2013) which states that fuel wood, charcoal and other forest products are the main cooking energy choice of rural dwellers while kerosene, gas and electricity are mainly used by urban dwellers. He continued by saying that, apart from low income level of rural dwellers, fuel wood and charcoal can easily be obtained from their neighborhoods and immediate surroundings but the reverse is the case for kerosene, gas and electricity. These are scarcely available in most rural communities of developing countries and households have little tendency of choosing modern types of cooking energy especially gas and electricity.

Table 5 - Factors influencing households' choice of cooking energy used in the study area

\begin{tabular}{|c|c|c|c|c|c|c|}
\hline \multirow{2}{*}{$n / n$} & \multicolumn{6}{|c|}{ Type of cooking energy } \\
\hline & Fuel wood & Charcoal & Kerosene & Gas & Electricity & Total \\
\hline \multicolumn{7}{|c|}{ Factors } \\
\hline Income & $4(3.08)$ & 15(11.54) & $7(5.38)$ & $4(3.08)$ & $3(2.31)$ & $33(25.38 \%)$ \\
\hline Weather & $3(2.31)$ & $11(8.46)$ & $2(1.54)$ & $1(0.77)$ & $5(3.85)$ & $22(16.92 \%)$ \\
\hline Types of dwelling place & $5(3.85)$ & $7(5.38)$ & $2(1.54)$ & $8(6.15)$ & $4(3.08)$ & $26(20.00 \%)$ \\
\hline Price & $4(3.08)$ & $2(1.54)$ & $4(3.08)$ & $4(3.08)$ & $3(2.31)$ & $17(13.08 \%)$ \\
\hline Nearness to source & $3(2.31)$ & $2(1.54)$ & $3(2.31)$ & $3(2.31)$ & $2(1.54)$ & $13(10.00 \%)$ \\
\hline Familiarity & $3(2.31)$ & $2(1.54)$ & $3(2.31)$ & $6(4.62)$ & $5(3.85)$ & $19(14.62)$ \\
\hline Total & $22(16.92)$ & $39(30.00)$ & $21(16.16)$ & $26(20.00)$ & $22(16.92)$ & $130(100.00)$ \\
\hline
\end{tabular}

Source: Field Survey, 2014.

Satisfaction obtained from the choice of cooking energy used. Table 6 revealed that the level of satisfaction obtained from fuel wood was low (6.15\%). Satisfaction from charcoal and gas were moderate $(7.69 \%)$ and $(5.38 \%)$ respectively. Satisfaction from kerosene was high $(6.92 \%)$ while that of electricity was very high $(6.15 \%)$. This study also revealed that though few households could afford the use of modern cooking energy such as kerosene, gas and 
electricity, they offered the highest level of satisfaction. It was also discovered that fuel wood, charcoal and kerosene make cooking of food more stressful as they darkened the cooking utensils and walls of kitchen/ cooking room easily. Washing of these utensils compounded the cook and often lead to frustration. These therefore reduce the levels of satisfaction obtained from using them. This study also revealed that though satisfaction obtained from using gas was moderate, many households could not afford using it regularly. The satisfaction obtained from electricity was very high because using it makes cooking fast, efficient, stress less and neat. Though, there may be irregular power supply, yet whenever it was available, a lot were always achieved compared to other choice of cooking energy. Moreover, the cost of using it was latent such that it would have been billed with other electric appliances in the house since the cost of using it for cooking was not billed separate. But, it is not advisable to depend on it alone since it supply is usually irregular in Nigeria.

Table 6 - Satisfaction obtained from the choice of cooking energy used

\begin{tabular}{|c|c|c|c|c|c|c|}
\hline \multirow{2}{*}{ Degree of satisfaction } & \multicolumn{6}{|c|}{ Types of cooking energy } \\
\hline & Fuel wood & Charcoal & Kerosene & Gas & Electricity & Total \\
\hline Very high & $0(0.00)$ & $5(3.85)$ & $7(5.38)$ & $4(3.08)$ & $8(6.15)$ & $(18.46)$ \\
\hline High & $1(0.77)$ & $5(3.85)$ & $9(6.92)$ & $3(2.31)$ & $6(4.62)$ & $(18.47)$ \\
\hline Moderate & $4(3.08)$ & $10(7.69)$ & $8(6.15)$ & $7(5.38)$ & $8(6.15)$ & $(24.61)$ \\
\hline Low & $8(6.15)$ & $6(4.62)$ & $5(3.85)$ & $2(1.54)$ & $4(3.08)$ & (19.24) \\
\hline Very low & $3(2.31)$ & $8(6.15)$ & $6(4.62)$ & $2(1.54)$ & $1(0.77)$ & $(19.23)$ \\
\hline Total & $16(12.31)$ & $34(26.16)$ & $35(26.92)$ & $18(13.85)$ & $27(20.77)$ & $(100.00)$ \\
\hline
\end{tabular}

Source: Field survey, 2014.

\section{CONCLUSION AND RECOMMENDATIONS}

The choices of cooking energy used in the study area are fuel wood, charcoal, kerosene, gas and electricity. The choice of cooking energy which households cannot do without in the study area is kerosene. Household choice of cooking energy is influenced by the dwelling place, monthly income, and types of occupation, weather, familiarity and nearness to source. Households with low monthly income chose their cooking energy among fuel wood, charcoal and kerosene. Households with high monthly income make their choice among kerosene, gas and electricity. The study revealed that they only used fuel wood and charcoal occasionally during festivals or when there was need to cook for large number of people.

The level of satisfaction obtained from kerosene, gas and electricity were high, moderate and very high respectively. It is therefore recommended that government should find means of increasing the welfare / standard of living of the households in the study area so that households will be able to afford gas and electricity as cooking energy. This will therefore protect them against the harmful effects of using charcoal, fuel wood and stove. Government and other stakeholders in energy and power sectors should find permanent solution to irregular electricity supply in the study area so that households will find it usage more dependable and reliable. Based on the fact that many people prefer to use gas for convenience, efficiency and neatness but cannot afford it, it is recommended that government should make gas available at cheaper rate as this will minimize environmental problems caused by the use of bio fuel. Government should provide a modern way of using this bio fuel so that the environmental and the health hazard of these types of energy sources. Similarly, the use of energy efficient stoves should be encouraged as this can greatly improve the combustion of fuel so that they emit very little smoke. All these would go a long way to improve the standard of living of women by giving them more time to do other income generating activities. 


\section{REFERENCES}

1. Adedire, M.O. (2002). Environment implications of tropical deforestation. The International Journal of Sustainable Development and World Ecology, Vol. 9, pp. 33-40.

2. Adeokun, O. A., Adekoya, A. E. \& Oloruntoba, A. (2003). Energy generation from livestock manure as a means of reducing Environmental pollution. Proceedings of 11th Annual Conference of Environment and Behavior Association of Nigeria (EBAN), pp. 274-278.

3. Arnold M.J.E., Kohlin G, Persson R (2006). Wood fuels, Livelihoods, and Policy Interventions: Changing Perspectives. World Dev. 34(3):596-611.

4. Brouwer R, Falcao MP (2004). Wood Fuel Consumption in Maputo, Mozambique. Biomass Energy. 27:233-245.

5. Census (2006). Nigerian National Population Commission -NPC.

6. Jande, J. A. (2005). Analysis of fuel wood consumption among the residents of Makurdi suburbs, Nigeria. In: Environmental Sustainability and Conservation in Nigeria,

7. Sene, E.H. (2000). 'Forests and food security in Africa; the place of forests in FAO's special food security', Unisylva (English Ed.) 51 (202) 13-18.

8. Kituyi E (2002). "Towards Sustainable Charcoal Production and Use: a Systems Approach." Proceedings of a Regional Workshop on Wood fuel Policy and Legislation in Eastern and Southern Africa. RELMA, Nairobi, Kenya.

9. Stephen, M.W (2011). Household Energy Consumption and Dependency on Common Pool Forest Resources: The Case of Kakamega Forest, Western Kenya. Dissertation to obtain the $\mathrm{Ph}$. D. degree in the International Ph. D. Program for Agricultural Sciences in Goettingen (IPAG) at the Faculty of Agricultural Sciences, Georg-August-University Göttingen, Germany.

10. Ogbonna D.O (1991). Energy Challenge and Ecological Balance in the Sahel and Semi-Arid Zone of Nigeria. A Paper Presented at the International Workshop on Ecology and Society in the History of the Sahel and Savanna, Centre for trans-Saharan Studies, University of Maiduguri.

11. Ogunsawa O.Y, Ajala O.O (2002). Firewood crises in Lagos- implication on the suburban and rural ecosystem management. In: J.E Abu, P.O Oni, L Popoola (eds). Proceeding of the 28th annual conference of Forestry Association of Nigeria at Akure, Ondo State. Nov. 4th 8th. pp. 257- 264.

12. The Solar Cooking Archive (2011) Fuel wood as percentage of energy consumption in developing countries. Retrieved on 23th August, 2012 from:http://solarcooking.org/fuelwood.htm.http://solarcooking.org/fuel wood.htm.

13. Zaku SG, Kabir A, Tukur, AA and Jimento I G (2013). Wood fuel consumption in Nigeria and the energy ladder: A review of fuel wood use in Kaduna State. Journal of Petroleum Technology and Alternative Fuels. Vol. 4(5), pp. 85-89. 